\title{
Seasonal Fluctuations of the Phytonematode Communities in Forage Legumes-Planted Field
}

\author{
Mahfouz M.M. Abd-Elgawad*, Mohamed F.M. Eissa*, Abd-Elmoneim Y. El-Gindi** \\ and Grover C. Smart ${ }^{\star * *}$ \\ * Phytopathology Department, National Research Center. \\ ** Department of Agricultural Zoology and Nematology, Faculty of Agriculture, University of Cairo, Giza, Egypt. \\ *** Department of Entomology and Nematology, IFAS, University of Florida, USA.
}

\begin{abstract}
Population levels of phytonematodes found in the upper $25-\mathrm{cm}$ soil planted with forage legumes were determined at monthly intervals for one year. Nematode species of Meloidogyne, Criconemella, Paratrichodorus, Tylenchorhynchus, Pratylenchus, Belonolaimus and Hoplolaimus reached almost peaked levels in fall at temperature range from $18.8-24.6{ }^{\circ} \mathrm{C}$. Also, most of these genera reached their lowest levels about forty days after removal of the host crop at a soil temperature of $29{ }^{\circ} \mathrm{C}$. Soil population densities of Meloidogyne spp., which were dominant through much of the year, fluctuated considerably. Paratrichodorus spp. declined progressively through the summer whereas Pratylenchus spp. were almost at nondetectable levels only during this period. Criconemella spp. were the only nematodes that had a progressive increase during summer months. Tylenchorhynchus spp. increased from non-detectable level in August to relatively high levels in the next two months. Species of Belonolaimus seemed to fluctuate in unison with that of Hoplolaimus spp. but both were of low densities through much of the year.
\end{abstract}

Key words: Belonolaimus, Criconemella, Hoplolaimus, Meloidogyne, Paratrichodorus, Pratylenchus, Tylenchorhynchus, precipitation, temperature.

\section{Introduction}

Nematodes are important pests of forage legumes in Florida, USA. However, information is scanty on the seasonal fluctuation of plant-parasitic nematode (PPN) populations in forage fields though such relevant studies are indispensable for the development of sampling plans and PPN control measures aimed at their application in integrated management programs. On the other hand, seasonal fluctuation of populations of several plant-parasitic nematodes on other crops has been studied. Barker et al. (1969) found that in North Carolina, soil population densities of juveniles of Meloidogyne spp. were lowest from June through September, highest in October and November, declined in January, increased in February, and declined again in March and throughout the spring in six fields 
planted with corn, cotton, watermelon, Johnson grass, tobacco and barely. They recovered maximum populations of Criconemella ornata in the fall followed by a second peak in February. Soil populations of Tylenchorhynchus claytoni varied significantly during the year according to nematode extraction methods. High populations of Belonolaimus longicaudatus occurred in fall and early winter and very low populations occurred in the spring and summer. Seinhorst (1970) speculated that in order to study the effects of external conditions on population densities of nematodes, one must have knowledge of the population dynamics of the nematode in order to set up adequate experiments and properly interpret results. This knowledge may include the relationship between initial density of nematodes and available space exploited for feeding, whether the nematodes attract or repel each other, the host range, and the life cycle of the nematode. Brodie (1976) reported that in Georgia, population densities of Pratylenchus brachyurus were highest during March, June and December when soil moisture was $22-42 \%$ by volume and soil temperature $14-17^{\circ} \mathrm{C}$. Highest densities of Paratrichodorus minor occurred during December through March when soil temperature was $11-17{ }^{\circ} \mathrm{C}$ and soil moisture was $18-23 \%$ by volume. Southwood (1978) stated that in general repeated or sequential sampling may be necessary to give a reliable census of polyspecific communities in which different species change differently with time. Forge et al. (1998) recorded population densities of Pratylenchus penetrans and the biomass of fine roots of raspberry at depths of $0-5,5-10,10-20$, and $20-30 \mathrm{~cm}$ every 2 weeks for 2 years. They found that the vertical distribution of $P$. penetrans varied from season to season, but the seasonal changes were not similar for the 2 years. In most seasons, the greatest population density was in the 5 to $10-\mathrm{cm}$-depth interval. Population densities of $P$. penetrans were not consistently correlated with the vertical distribution of raspberry roots in any season. Siddiqui (2007) studied the seasonal changes of the population of plant parasitic nematodes viz., Hoplolaimus indicus, Helicotylenchus indicus, Rotylenchulus reniformis, Tylenchorhynchus mashoodi, Tylenchus filiformis and Hemicriconemoides mangiferae around the roots of mango, Mangifera indica L., an economically important fruit tree. The population was investigated at 10, 20 and $40 \mathrm{~cm}$ depths. It was observed that seasonal fluctuations have a direct effect on the nematode population. The population was larger at $10 \mathrm{~cm}$ depth followed by 20 and $40 \mathrm{~cm}$ depths. The largest nematode population was observed when the percent soil moisture was high. Both soil temperature and soil moisture were equally important. The soil $\mathrm{pH}$ also affected indirectly the nematode population densities. DinardoMiranda and Fracasso (2010) examined the spatial and temporal variability of plant-parasitic nematodes population in sugarcane in two commercial fields of approximately 1 ha, both of them infested by Meloidogyne javanica and Pratylenchus zeae. Samples represented by about $50 \mathrm{~g}$ of roots, were collected every two months, within a grid measuring $10.5 \times 10 \mathrm{~m}$ (experiment 1 ) and $9.8 \times 10 \mathrm{~m}$ (experiment 2). The highest nematodes populations were obtained during the rainy 
season, when high temperatures and moistures were favorable to root development. For this reason they considered the rainy season as the best time to collect samples to identify areas with nematodes problem. Renco et al. (2010) studied the seasonal fluctuation of nematode population during three vegetation periods (2005-2007), at 20 and $40 \mathrm{~cm}$ soil depth, from May to October, in a hop garden at Nemšová (Slovak Republic). The seasonal fluctuation of the nematode population was related to temperature and rainfall. At $20 \mathrm{~cm}$ soil depth of each year, the largest nematode population was recorded in July, and the smallest from July to October. At $40 \mathrm{~cm}$ soil depth, nematode abundance was not significantly different between the years 2006 and 2007. In general, at the same depth, a decrease of nematode abundance was observed from May to October.

Current losses due to PPNs have been estimated up to the tune of US\$358.24 billion annually on a worldwide basis, which is undoubtedly a serious threat to the world economy (Abd-Elgawad and Askary, 2015). So, this study aimed at shedding light on the seasonal fluctuation of PPN on some forage legumes commonly grown in Florida.

\section{Material and Methods}

The site of this study was in a legume field on the main Agronomy Farm, University of Florida (UF), Gainesville, USA. The soil is a well-drained Arredondo fine sand. The experimental area, measuring $90 \times 60 \mathrm{~m}$, was divided into 18 plots; each of $20 \times 15 \mathrm{~m}$. About eight $2.5-\mathrm{cm}$ diameter cores were taken randomly within the root zone (upper $25 \mathrm{~cm}$ ) from each plot and then mixed thoroughly to form one sample representing the plot. Each sample was placed in a plastic bag, stored in an ice chest, and transported to the nematology laboratory. Samples not processed immediately were stored at $10 \pm 1^{\circ} \mathrm{C}$ until processed. Nematodes were extracted from $100 \mathrm{~cm}^{3}$ soil from each sample using a centrifugal-flotation technique (Caveness and Jensen, 1955), placed in vials, and stored in a refrigerator at $4{ }^{\circ} \mathrm{C}$ for no more than three days until identified to genera/species and counted. Nematode means of the eighteen plots were used in the study. Sampling was done at monthly intervals, during the first week of the month, from May 1983 through April 1984. Monthly temperature of soil at a depth of $10 \mathrm{~cm}$ was cited from climatological data recorded by the Agronomy Department University of Florida, and National Oceanogrophic and Atmospheric Administration (NOAA) Cooperating. The field had been in cultivation with seasonal legumes, included breeding programs, for several years before sampling. Cropping history and cultural practices during the year of sampling are given in table (1). Primarily, the plots were watered by rainfall (Table 2 ), but water was applied by overhead irrigation where plants were severely drought-stressed. 
Table (1): Cropping history and cultural practices.

Date

$11 / 17 / 1981$

6/20/1982 Clovers were harvested using a hand sickle.

7/8/1983 The field was sprayed with fusillade (herbicide) at $1 / 2 \mathrm{pt} /$ Acre.

7/22/1983 The field was plowed.

7/27/1983 The field was fertilized $9400 \mathrm{Lb} /$ acre of 0-10-20 analysis, disked, sprayed with vernam (herbicide) and disked again.

8/3/1983 Cowpea (cultivars Texas crea; 40 and Purple knuckle hull) was planted replacing red clover.

10/11/1983 Vegetation was mowed and the field was plowed.

10/14/1983 The field was sprayed with Balan (3Qt/ Acre) and vernam 2.5 pt/Acre) as herbicides and disked.

10/27/1983 The field was fertilized as on $7 / 27 / 1983$.

10/31/1983 About half of the field was planted with Florida red clover. White clover was planted at $1 / 6$ of the field replacing arrowleaf clover and $1 / 3$ of the field was left fallow.

11/17/1983 Planted 'Wren's abruzi' rye at edge of the field.

$12 / 10 / 1983$ Planted lupine in $1 / 6$ of the field but it was killed late in December by the freeze.

12/19/1983 Red clover was spaced ${ }^{+}$using cultivator attached to a tractor.

2/2/1984 Red clover was spaced again.

4/5/1984 Red clover was harvested

6/7/1984 White clover was harvested.

* 'Florida' red clover, included in a breeding program, was transplanted in 1981 as cycle 5 and in 1983 as cycle 6 with plants spaced one meter apart.

** Arrowleaf clover and white clover were spaced one meter apart.

${ }^{+}$The common weeds in the field were eastern flower and primrose and volunteer peanut plants. 
Table (2): The amount of rain precipitation influencing months of sampling.

\begin{tabular}{ll}
\hline Month & Rain (centimeter) \\
\hline 1983 & \\
April & 10.6 \\
May & 10.67 \\
June & 25.50 \\
July & 9.30 \\
August & 4.17 \\
September & 27.81 \\
October & 3.45 \\
November & 11.51 \\
December & 15.01 \\
1984 & \\
January & 3.02 \\
February & 12.09 \\
March & 8.23 \\
\hline
\end{tabular}

\section{Results}

Nematodes commonly encountered as parasites of the legume crops in this study were Meloidogyne spp., Criconemella spp., Paratrichodorus spp., Hoplolaimus spp., Belonolaimus spp., Tylenchorhynchus spp. and Pratylenchus spp. Each of the first three nematode genera were often more abundant than any of the others.

Soil nematode populations and soil temperatures at the experimental site for the year around are graphically summarized in Figure 1. The highest population density of nematodes occurred during October, with lower peaks in May and April when soil temperatures were $76^{\circ} \mathrm{F}\left(24.5^{\circ} \mathrm{C}\right), 77^{\circ} \mathrm{F}\left(25^{\circ} \mathrm{C}\right)$ and $70{ }^{\circ} \mathrm{F}\left(21.1^{\circ} \mathrm{C}\right)$, respectively, and the lowest population density occurred in August; after about forty days of fallow, with another decline in January at soil temperatures $84.5^{\circ} \mathrm{F}\left(29^{\circ} \mathrm{C}\right)$ and $55^{\circ} \mathrm{F}\left(12.8^{\circ} \mathrm{C}\right)$, respectively.

Population densities for each of the seven genera of plant-parasitic nematodes peaked in October or November with a lower peak in April or May (Fig. 2). Soil populations of second stage juveniles of Meloidogyne peaked in November when the soil temperature was $66^{\circ} \mathrm{F}\left(18.5^{\circ} \mathrm{C}\right)$ preceded by $76{ }^{\circ} \mathrm{F}\left(24.5^{\circ} \mathrm{C}\right)$ in October. Populations of Criconemella spp. and Tylenchorhynchus spp. peaked in October at a soil temperature of $76^{\circ} \mathrm{F}\left(24.5^{\circ} \mathrm{C}\right)$, Paratrichodorus spp. in March at $64.5^{\circ} \mathrm{F}\left(18^{\circ} \mathrm{C}\right)$, Belonolaimus spp. and Pratylenchus spp. in April at $70.3^{\circ} \mathrm{F}$ $\left(21.3^{\circ} \mathrm{C}\right)$ and Hoplolaimus spp. in May and April at $76.5^{\circ} \mathrm{F}\left(24.7^{\circ} \mathrm{C}\right)$ and $70.3^{\circ} \mathrm{F}$ 
$\left(21.3^{\circ} \mathrm{C}\right)$. Most genera reached the lowest population densities or even nondetectable levels in August. Thereafter, the populations of all genera, except Belonolaimus spp., began to increase. However, it may be noteworthy that the population densities of Hoplolaimus spp. and Belonolaimus spp. were low throughout the year and varied almost in unison.

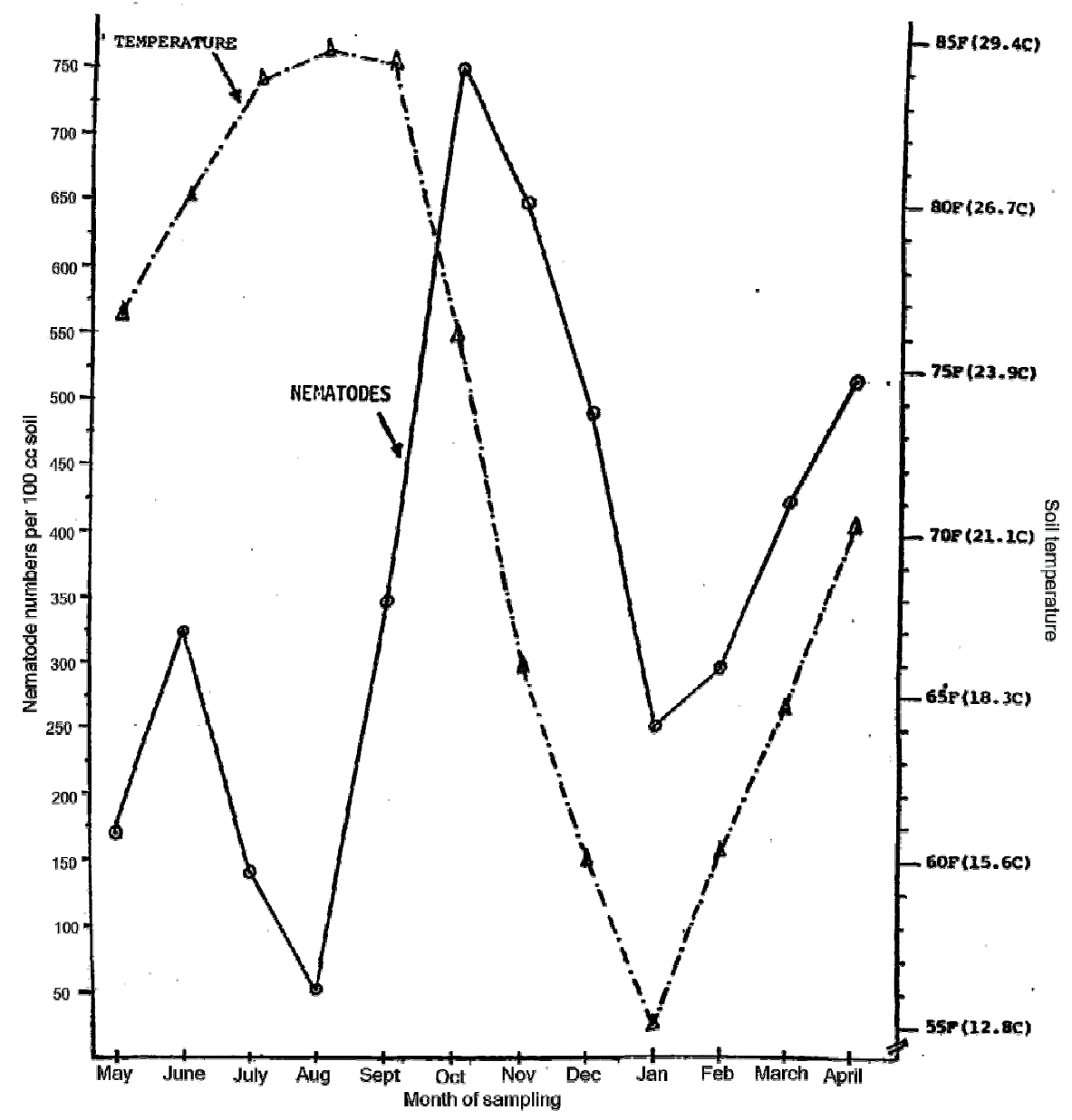

Figure (1): The reationship between plant-parasitic nematode populations, associated forage legumes, and soil trmperatures for one year.

There were some similarities between the distribution patterns of Meloidogyne spp. and Criconemella spp. although Meloidogyne spp. reached their peak levels earlier in June and later in November. Species of Paratrichodorus spp. followed similar patterns except that the three nematode genera were having different trends in the earlier months of sampling. Population levels of Tylenchorhynchus spp. and Pratylenchus spp. were more or less similar through most of the year. 


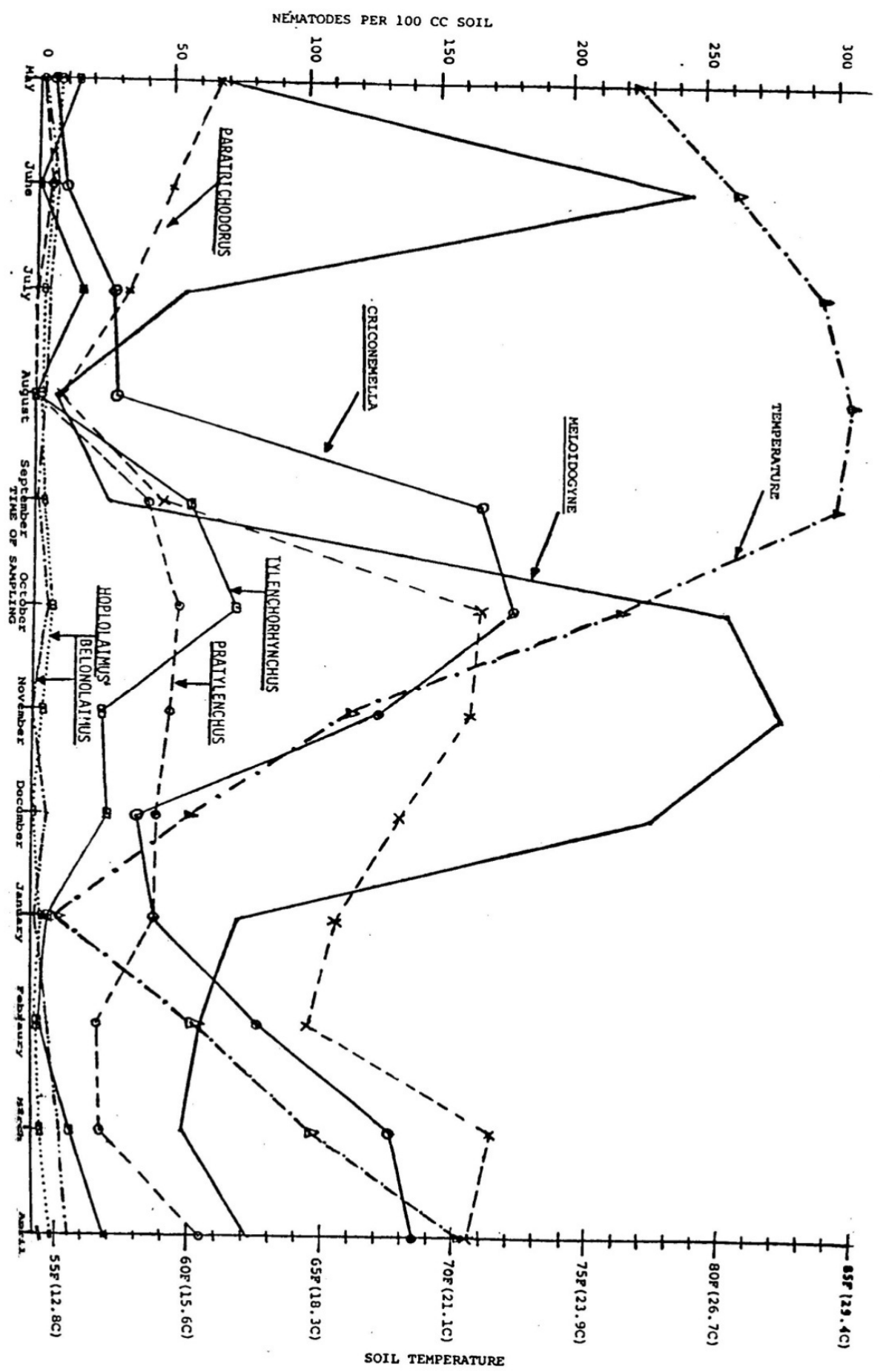

Figure (2): Seasonal changes in numbers of nematodes associated with forage legumes. 
Although rainfall data were available, we did not measure the field moisture or the amount of water applied by irrigation. Also, it was unreasonable to make analyses of variance and compare the means of nematode populations throughout the year because of the biased differences in nematode distribution among field plots resulting from crop distribution. An impression gained from this study was that nematode genera of Hoplolaimus spp., Belonolaimus spp., Tylenchorhynchus spp., and Pratylenchus spp. could not reproduce on these used legumes as readily as Meloidogyne spp. did. The changes in population densities of Criconemella spp. during the earlier months of sampling could not be explained.

\section{Discussion}

A polyspecific community, consisting of seven genera of plant-parasitic nematodes occurred in soil planted with legume crops. This work documented the marked fluctuations of nematode population densities throughout the year. Meloidogyne spp. reached peak population level at the midseason of the growing cowpea which agreed with Rickard and Barker's report (1982) on Meloidogyne incognita, in the southeastern United States. However, our Meloidogyne population reached a second peak level in June before harvesting the clovers. The sufficient amount of rainfall early in June possibly contributed to this peak since the juveniles hatch readily when there is enough water in the soil as reported by Taylor and Sasser (1978). Also, the similarity noted between the distribution patterns of Meloidogyne spp. and other populations may be related to the distribution patterns of the planted crop and its history.

The population level of Paratrichodorus spp. followed a downward slope during the summer months as reported by Brodie (1976). It may be that when the soil near the surface gets above a certain temperature the nematodes migrate deeper into the soil and thus out of the sampling Zone. However, many factors may be involved.

Maximum numbers of Criconemella spp. were recovered in the fall followed by a second peak in April. Barker et al. (1969) reported the second population peak of Criconemella ornata to occur in February in North Carolina. This difference in time might be due to the difference in cropping system and/or microclimates.

In the months monitored, population densities of Pratylenchus spp., Tylenchorhynchus spp., Belonolaimus spp. and Hoplolaimus spp. were at lower levels than those of Meloidogyne spp., Criconemella spp. and Paratrichodorus spp. Nevertheless, our results completely agreed with those of Barker and Campbell (1981) who reported that species of Pratylenchus parasitic on annual plants may be overlooked in soil samples taken during summer as specimens are inside the roots. Population levels of Tylenchorhynchus spp. reached a peak during the fall whereas population levels of Hoplolaimus spp. and Belonolaimus spp. were too low to be of significant importance through much of the year. 
In general, nematode populations reached the lowest levels in August possibly associated with harvesting the crop as well as the highest temperatures. The fluctuation of Criconemella spp. population densities during the earlier months of sampling was unexpected since the nematode increased in the fallow soil. This makes our sample size questionable since the number of samples from normally distributed populations is proportional to sampling precision. Goodell (1979) and Goodell and Ferris (1978) showed that with appropriate designs, acceptable precision in sampling for nematodes can be achieved. Therefore, we took the same proportion of samples that they recommended in their investigations into optimum sample size, i.e. one $2.5-\mathrm{cm}$ core per 36 square meter of the field. However, they took the samples to the depth of $45 \mathrm{~cm}$ in alfalfa field whereas our sample depth was $25 \mathrm{~cm}$. That is because the majority of nematodes on most annual crops are found in the upper $30 \mathrm{~cm}$ of soil as reported by Rossner (1972) and Brodie (1976). Nevertheless, aggregated spatial distribution of nematodes and changes of the typical polyspecific communities over time pose a major problem for such a study as reported by Barker and Campbell (1981). This study may contribute to the establishment of a simple descriptive model in which plant, nematode, and environment are considered as an interacting system with a few major factors responsible for changes in nematode populations.

\section{References}

Abd-Elgawad, M.M.M. and Askary, T.H. (2015). Impact of phytonematodes on agriculture economy. In: Askary, T.H. and Martinelli, P.R.P. (eds) Biocontrol Agents of Phytonematodes. Wallingford, CAB International, UK, pp. 3-49.

Barker K.R. and Campbell C.I. (1981). Sampling nematode populations. In: Zuckerman, B.M. and Rohde R.A. (eds) Plant Parasitic Nematodes, vol. III. Academic Press, New York, USA, pp. 451-474.

Barker, K.R., Nusbaum, C.J. and Nelson, L.A. (1969). Seasonal population dynamics of selected plant-parasitic nematodes as measured by three extraction procedures. Journal of Nematology 1, 232-239.

Brodie, B.B. (1976). Vertical distribution of three nematode species in relation to certain soil properties. Journal of Nematology 8, 243-247.

Caveness, F.E. and Jensen, H.J. (1955). Modification of the centrifugal-flotation technique for the isolation and concentration of nematodes and their eggs from soil and plant tissue. Proceedings of the Helminthological Society of Washington 22, 87-89.

Dinardo-Miranda, L.L. and Fracasso, J.V. (2010). Spatial and temporal variability of plant-parasitic nematodes population in sugarcane. Bragantia Campinas 69, 39-52. 
Forge, T.A., Deyoung, R. and Vrain, T.C. (1998). Temporal changes in the vertical distribution of Pratylenchus penetrans under Raspberry. Journal of Nematology 30(2), 179-183.

Goodell, P.B. (1979). Distribution of plant-parasitic nematodes in alfalfa. M. Sc. Thesis, University of California, Riverside, California, USA.

Goodell, P.B. and Ferris, H. (1978). Investigations into optimum sample size and pattern for estimating nematode population densities. Journal of Nematology 10, 289.

Renco, M., Liskova, M. and Cerevkova, A. (2010). Seasonal fluctuations of the nematode communities in a hop garden soil. Helminthologia 47, 115-122.

Rickard, D.A. and Barker K.R. (1982). Nematode assays and advisory services. In: Riggs, R.D. (ed.) Nematology in the Southern Region of the United States. Arkansas Agricultural Experiment Station, Southern Cooperative Services Bulletin 276, Fayetteville, USA, pp 8-20.

Rössner, J. (1972). Vertical distribution of migratory root nematodes in soil in relation to water-content and extent of root system. Nematologica 18, 360372.

Seinhorst, J.W. (1970). Dynamics of populations of plant parasitic nematodes. Annual Review of Phytopathology 8, 131-156.

Siddiqui, M.A. (2007). Seasonal fluctuation in nematode population associated with mango, Mangifera indica L. Archives of Phytopathology and Plant Protection 40(6), 389-394.

Southwood, T.R.E. (1978). Ecological methods, with particular reference to the study of insect populations. 2nd edn. Chapman and Hall, London.

Taylor, A.L. and Sasser, J.N. (1978). Biology, identification and control of root knot nematodes (Meloidogyne species). Collaborative Publication, Department of Plant Pathology, North Carolina State University, and US Agency International Development, Raleigh, North Carolina, North Carolina State University Graphics, USA, 111 pp. 


\section{الملخص العربي}

التذبذب الموسمي لمجتمعات نيماتودا النبات في حقل بقوليات علفية

محفوظ محمد مصطفى عبد الجواد*، محمد فهمي محمد عيسي*، عبد المنعم ياسين الجندي**،

$$
\text { وجروفر سمارت }
$$

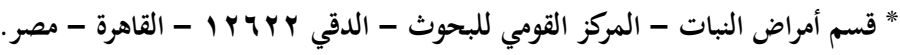

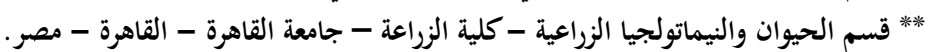

ث**** قسم الحشرات والنيماتولجي - معهد علوم الغذاء والزراعة - جامعة فلوريدا - الولايات المتحدة الأمريكية.

تم تحديد مستويات تعداد نيماتودا النبات الموجودة في الجزء العلوي - هب سم - من التربة

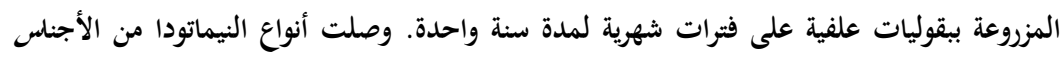

Tylenchorhynchus ،Paratrichodorus ،Criconemella ،Meloidogyne في Hololonolaimus ،Pratylenchus و مستويات ذروتها تقريبًا في الخريف

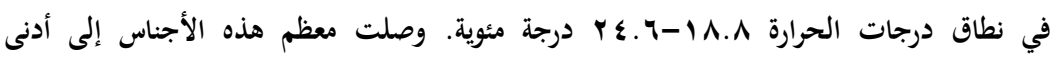

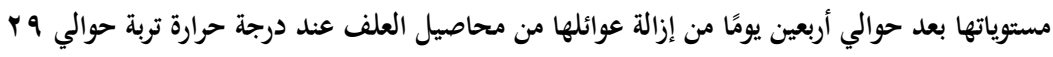

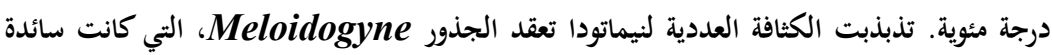

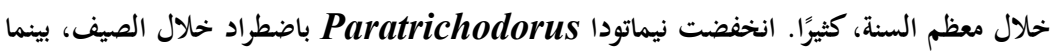

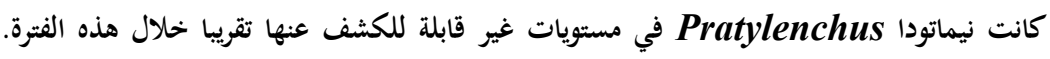
كانت Criconemella الديدان الوحيدة التي سجلت زيادة مضطردة خلال أشهر الصيف. أزداد تعداد نيماتودا Tylenchorhynchus من مستوى غير قابل للكشف في أغسطس إلى مستويات

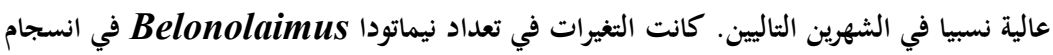
تام مع تلك الحادثة مع نيماتودا Hoplolaimus ولكن كلاهما كان ذو كثافة منخفضة خلال

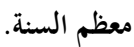

